\title{
Apresentação
}

\section{Descolonizar o conhecimento, conhecer para transformar}

O Celacc organizou em 20 de outubro de 2017 o Colóquio Brasil-Colômbia de Metodologias Participativas em Estudos sobre Cultura, Comunicação e Território. Este evento foi construído durante a estada em Bogotá da equipe do projeto de pesquisa "Movimentos Sociais, Cultura, Comunicação e Território na América Latina" financiado pela FAPESP em junho e julho de 2017.

Em contato com vários pesquisadores de universidades, como a Universidad Minuto de Dios (Uniminuto) em particular o Cientro de Estudios para el Desarollo (CED); Universidad Externado, Universidad Nacional e outros intelectuais colombianos, tivemos a grata surpresa de que a metodologia participativa utilizada no nosso projeto de pesquisa também era discutida e aplicada em várias pesquisas realizadas pelos intelectuais colombianos.

Uma das características das metodologias participativas é a articulação e indissociabilidade entre pesquisa, ensino e extensão. Com isto, estabelece-se um compromisso da academia com as demandas da sociedade e dos movimentos sociais fazendo com que a produção científica não seja uma mera erudição distanciada da realidade, mas um exercício constante de reflexão, entendida esta como pensar o feito (re-fletir) e contribuir para a constituição de novas estratégias.

Nos anos 1970 e 1980, a prática das metodologias participativas se inseria no engajamento político de intelectuais comprometidos com os movimentos sociais, em especial em países que passaram por ditaduras militares, como foi o caso do Brasil, Argentina, Uruguai, Chile. A grande inspiração teórica deste paradigma metodológico foi o educador brasileiro Paulo Freire cujas obras dos anos 1960 apontavam a necessidade da educação ser um espaço para a construção de uma reflexão crítica da realidade e se constituir como uma ação cultural para a libertação. ${ }^{1}$

Os escritos de Paulo Freire muito se aproximam de uma tradição do pensamento latino-americano que considera a existência de uma "colonialidade do poder" e a necessidade de se construir uma perspectiva descolonial. Isto porque não se constata apenas uma estrutura de opressão do capital, como uma reflexão no paradigma marxiano nos aponta. Mas a este capitalismo também se inclui uma singularidade, que é o seu caráter dependente e tardio. Mais que isto ainda, que as nações latino-americanas tiveram boa parte da sua história marcada pela colonização europeia e por embates pela descolonização, tanto no aspecto político, como cultural - aqui é importante transcender de uma ideia de conflito cultural para além do pensamento gramsciano de se pensar a

1 Ver Paulo FREIRE. Pedagogia do oprimido. Rio de Janeiro: Paz e Terra, 1970. 
cultura popular como bricolage e senso comum, ${ }^{2}$ mas como resistência identitária de povos originários (indígenas) e transplantados forçadamente (africanos e afrodescendentes) que foram escravizados, massacrados e destituídos das suas subjetividades.

Quando Paulo Freire articula o conceito de "cultura do silêncio" com o passado colonial em que a "metrópole fala, a colônia escuta", sinaliza que a sua proposta de ação cultural para a liberdade é uma práxis descolonizadora. Assim como o filósofo argentino Enrique Dussel, na sua proposta de uma filosofia da libertação ser construída a partir da voz dos segmentos subalternizados. ${ }^{3}$

Por isto, a recuperação da perspectiva metodológica participativa é também um esforço teórico para se construir um pensamento descolonial. A opressão do capital globalizado nos dias de hoje se realiza pelo estabelecimento de um sistema-mundo em que os centros de comando do capital se legitimam pela concentração da ciência, tecnologia e conhecimento denso; e a base de sistema resta apenas a aplicação destes conhecimentos, muitas vezes não só estranhos a sua realidade mas também que servem como sustentáculos ideológicos da colonialidade do poder.
O compromisso estabelecido pelos pesquisadores desta perspectiva metodológica não se limitam as suas relações e aproximações com os movimentos sociais e, principalmente, a darem vozes a estes segmentos. Para além disto, ao buscar a construção de reflexões teóricas a partir dos diálogos estabelecidos com os sujeitos inseridos nos contextos das sociedades latino-americanas, o resultado aponta para a necessidade de elaboração de conceitos que rompam com a colonialidade do conhecimento, uma das variantes da colonialidade do poder.

Com este evento e a edição desta edição especial do Extraprensa, o Celacc reafirma o compromisso com o seu lema, criado pela sua fundadora, professora Maria Nazareth Ferreira: América Latina, conhecer para transformar.

Boa leitura

\section{Prof. Dr. Dennis de Oliveira}

Junho de 2018 Coordenador do Celacc

2 Ver Álvaro BIANCHI. O laboratório de Gramsci. Campinas: Alameda Editorial, 2008.

3 Enrique DUSSEL. Filosofia da libertação. S. Paulo: Edições Loyola, 1978. 